\title{
Debris flow hazard and mitigation works in Fiames slope (Dolomites, Italy)
}

\author{
P. R. Tecca ${ }^{1}$, C. Armento $^{2} \&$ R. Genevois ${ }^{2}$ \\ ${ }^{1}$ CNR-IRPI, Padova, Italy \\ ${ }^{2}$ Department of Geology, Padova University, Italy
}

\begin{abstract}
Active debris flow scree in the territory of Cortina d'Ampezzo (Dolomites, Italy) seriously threatens the urbanized areas and the state road. In September 1997, following a $25.000 \mathrm{~m}^{3}$ magnitude debris flow that temporarily dammed the river, a retention basin with a storage capacity of about $15000 \mathrm{~m}^{3}$, was built upstream the state road. In this paper, the effectiveness of the existing debris basin has been evaluated regarding to the magnitude of the design debris flow. Based on geomorphological and historical data, major events up to $30.000 \mathrm{~m}^{3}$ may be possible. To avoid destruction caused by debris flows, new mitigation measures are planned. Proper zoning is implemented, but for the state road cannot be relocated, both passive and active mitigation measures must be adopted. A warning system has been designed, based on both the early detecting of debris flow-induced ground vibrations and the overcoming of rain thresholds, for stopping the traffic on the state road in the event of a debris flow. As it is not possible to mitigate debris flows along the flow paths, the most suitable action to reduce the risk is to control the debris deposition. Proper design requires an estimate of the magnitude, frequency and delineation of debris flow hazard and risk of the site, together with fundamental information such as possible runout distances, depth, velocities and impact force of a design debris flow. For this purpose, a two-dimensional flow routing model, FLO-2D, has been used, based on a detailed DEM of the site, data collected in a similar neighbour debris flow monitored site and reasonable assumptions regarding sediment concentration and other rheological parameters. A more effective design of a retention basin is proposed.
\end{abstract}

Keywords: debris flows, Dolomites, FLO-2D, mitigating measures. 


\section{Introduction}

Debris flows are a severe natural hazard in mountainous regions killing people and causing remarkable property damage, due to their high velocity, large volumes and frequent recurrence. Accurate prediction of extent of the inundated areas, velocities and sediment depths can reduce these losses, by providing a means to delineate hazard areas and implementing zoning restrictions, and parameters for design of protective measures.

Limited data are still available on monitoring of debris flow, amongst them in Japan (Suwa [1]), in China (Zhang [2]), and more recently in Italy (Tecca et al. [3]; Arattano and Marchi [4]), modelling of debris flows may be an extremely useful tool in hazard and risk management.

First attempts to simulate debris flows were accomplished with onedimensional flow-routing models (De Leon and Jeppson [5], Schamber and MacArthur [6]). Two-dimensional finite differences models are widely considered more appropriate to describe different flow regimes and predict inundation areas, using a range of rheological behaviour of the flow (MacArthur and Shamber [7], Takahashi and Tsujimoto [8], Takahashi and Nakagawa [9]). In 1985, O'Brien and Julien [10] proposed a quadratic shear stress model that seems the most appropriate to describe the continuum of flow regimes from viscous to turbulent/dispersive flow. The FLO-2D model, conceived for routing non-Newtonian flows (O'Brien et al. [11]), uses variable area cross sections, predict channel overbank discharge, and simulate floodplain flow over complex topography. It is suitable also on developed fans as it accounts for flow path obstructions.

This paper presents numerical modelling of a debris flow that seriously threatens a developed area and a state road at Fiames (Eastern Dolomites, Italy). Fiames is a hill-slope debris flow and often varies its flow path from event to event; blockage or overflowing in the middle and lower path may cause avulsion. Discharges of debris often result in blockage of the road, damaging houses and damming the Boite River. As a first step we calibrated the numerical model against field data of a well-documented event. In the second step we applied the selected values to different scenarios to evaluate the effectiveness of an existing debris basin respect to the design debris flow and to design more appropriate countermeasures.

\section{Geological and geomorphological settings}

Fiames slope is located on the left side of the Boite River valley, near Cortina d'Ampezzo, in the Eastern Dolomites Italy (fig. 1). The upper rock basin is formed of Upper Triassic to Lower Jurassic massive dolomite and limestone cliffs that are the source of coarse debris and boulders, accumulating on the slopes below and in the Graa de Longes channel. A thick talus covers the slope from the base of the rock cliffs to the valley bottom (1265 $\mathrm{m}$ a.s.1.); it consists of poorly sorted debris containing boulders up to 3-4 $\mathrm{m}$ in diameter and includes heterogeneous scree, alluvium and old debris flow deposits. The initiation area of 
the debris flow is located between 2178 and $1732 \mathrm{~m}$ a.s.1; the main channel is incised into the talus, with depths ranging from $3 \mathrm{~m}$ to $6 \mathrm{~m}$ and widths from $10 \mathrm{~m}$ to $22 \mathrm{~m}$.

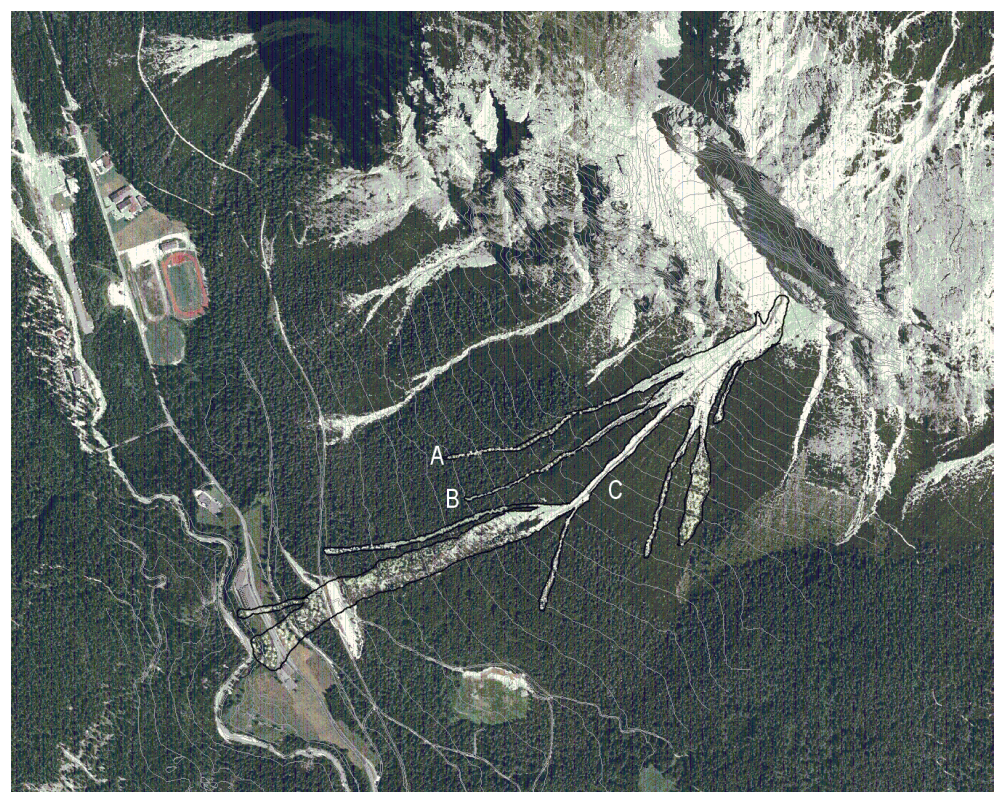

Figure 1: $\quad$ Fiames rock basin and slope. Observed September 5, 1997 flooded area in thick black line with channels A, B, and C.

The main morphometric parameters of Fiames site are listed in Table 1.

Table 1: $\quad$ Main morphometric parameters of Fiames site.

\begin{tabular}{ll}
\hline rock basin area $\left(\mathrm{km}^{2}\right)$ & 0.16 \\
basin maximum elevation (m a.s.l.) & 2450 \\
upper basin outlet elevation (m a.s.1.) & 1845 \\
rock basin mean slope $\left(^{\circ}\right)$ & 40 \\
total channel length (m) & 1500 \\
mean channel slope $\left(^{\circ}\right)$ & 20 \\
start of deposition area elevation (m a.s.l.) & 1480 \\
deposition area mean slope & 10 \\
\hline
\end{tabular}

Three main channels (a, b, c) and some minor ones originate from the same source area and are related to different events. Historical records on debris flows at Fiames exist back to the $19^{\text {th }}$ century. Most recent flows, from 1992 to 1998 , had volumes ranging from $8000 \mathrm{~m}^{3}$ to $25000 \mathrm{~m}^{3}$. 


\section{The event of 5 September 1997}

On September 5, 1997 a debris flow occurred, temporarily damming the Boite River. The event was triggered by an intense rainstorm recorded by a rain gauge $1 \mathrm{~km}$ far north, at an elevation of $1325 \mathrm{~m}$. The event initiated at the onset of the main channel. At an elevation of $1480 \mathrm{~m}$, where the slope angle decreases to $20^{\circ}-23^{\circ}$, from the main channel some accessory channels originated. Further downslope, where the slope angle decreases to $12^{\circ} \div 14^{\circ}$, the lateral deposits become more and more evident while the main channel proceed straight through the wood down to the National Road and the Boite River. The total volume of the transported material has been estimated in $25000 \mathrm{~m}^{3}$. About $52 \%$ of the total volume deposited on the slope below $1480 \mathrm{~m}$ a.s.l. with depths of $0.8-1.1 \mathrm{~m}$, whilst the remainder flowed further downslope to the Boite River. A few months later a retention basin with a storage capacity of about $15000 \mathrm{~m}^{3}$, was built upstream the state road.

\section{Geotechnical characteristics}

Samples were collected in the initiation areas, along the flow channels and in the deposition zone. The Fiames debris flow transports gravely-sandy poorly sorted material, ranging in size from silt and clay to big boulders (up to 1-2 $\mathrm{m}$ in diameter). The fraction finer than $2 \mathrm{~mm}$ does not display any plasticity and direct shear tests on saturated samples have proved the material is cohesionless. The main geotechnical properties are presented in Table 2.

Table 2: Debris properties.

\begin{tabular}{ll}
\hline \multicolumn{1}{c}{ property } & \multicolumn{1}{c}{ value } \\
\hline cohesive strength & $0 \mathrm{~Pa}$ \\
effective internal friction angle & $38^{\circ}-42^{\circ}$ \\
void ratio & $0.33-0.66$ \\
unit weight & $20.2-21.4 \mathrm{kN} / \mathrm{m}^{3}$ \\
$\mathrm{D}_{60} / \mathrm{D}_{30}$ ratio & $3.9-14.3$ \\
\hline
\end{tabular}

\section{The numerical simulation}

\subsection{The FLO-2D model}

FLO-2D is a two-dimensional finite difference routing model for water and nonNewtonian flows on alluvial fans, with both channel and unconfined overland flow components. The surface topography is discretized into square-grid elements, each one is assigned an elevation and a roughness factor; the detail and accuracy of a simulation are related to grid size. The flood hydrograph is routed using either a kinematic, diffusive or dynamic wave approximation to the momentum equation; the last equation is the most appropriate to simulate debris flows (FLO-2D [12]). When routing hyperconcentrated flows such as mud or 
debris flows, the momentum equation includes the viscous and yield stresses. For a complete discussion of the model attributes, see the FLO-2D User's Manual (FLO-2D [12]). The model can predict a reasonable area of inundation, the probable range of flow velocity and depth and simulates flow cessation, maintaining mass conservation for both the water and sediment volumes (O'Brien et al. [11]). The viscosity $\eta$ and the yield stress $\tau_{y}$ of the mixture vary principally with volumetric sediment concentration $\mathrm{C}_{\mathrm{v}}$ and are defined by the following empirical relationships:

$$
\eta=\alpha_{1} e^{\beta_{1} C_{v}}
$$

and

$$
\tau_{y}=\alpha_{2} e^{\beta_{1} C_{v}}
$$

in which $\alpha_{\mathrm{i}}$ and $\beta_{\mathrm{i}}$ are empirical coefficients defined by laboratory tests (O'Brien and Julien [13]). FLO-2D is a rigid bed model, but this is not a serious limitation because to get a rough estimate of channel bed scour it is suggested to multiple the channel bed width and length by an estimate of the average scour; a similar sediment volume estimate can be made for bank failure (O’Brien [14]).

\subsection{FLO-2D routing analysis}

\subsubsection{Calibration of the model}

To simulate with good precision, both the flooded area and the thickness of debris deposited by the design debris flow, the observed flow behaviour at Fiames on the event occurred on September 5, 1997 has been replicated.

A total volume of $25000 \mathrm{~m}^{3}$ was released over the slope, from the actual debris flow initiation zone, at an elevation of $1732 \mathrm{~m}$ a.s.1..

A DEM of the area, with a cell size of $5 \mathrm{~m}$, has been built from topographic vectorial data of the cartographic base at scale 1:2000. The DEM was imported in the FLO-2D pre-processor GDS to generate a 5 x $5 \mathrm{~m}$ grid of 34396 elements. The water hydrograph used to replicate the debris flow of September 5, 1997 has been obtained applying the hydrologic model CLEM (Cazorzi [15]) to the rainfall recorded on the same date in the nearby meteo station of Faloria (BL), assuming flow velocities of $2 \mathrm{~m} / \mathrm{s}$ and $0.03 \mathrm{~m} / \mathrm{s}$ in the flow net and over the slope respectively. A sediment concentration by volume was assigned to the hydrograph, ranging between not less than 0.3 along the rising and falling limbs of the hydrographs, and a maximum of 0.60 corresponding to a mature debris flow. The peak discharge was assigned a sediment concentration slightly less than the frontal wave to account for water dilution (fig. 2).

The Manning's n-value was 0.1, typical for open ground with debris; the specific weight of the mixture $\gamma_{\mathrm{m}}$ and the resistance parameter for laminar flow $\mathrm{K}$, were assumed equals to $26.5 \mathrm{kN} / \mathrm{m}^{3}$ and 2285 respectively, suggested values for debris flows (FLO-2D [12]).

Calibration of the model is a crucial aspect for prediction of debris flow hazard. Available data from the event included: (1) the extent of the flooded area indicated from photography and field survey and the runout distance; (2) a surveyed volume of the debris flow deposit of about $25000 \mathrm{~m}^{3}$; (3) debris flow 
velocity estimated using the superelevation approach by Johnson and Rodine [16] $(2.9-4.0 \mathrm{~m} / \mathrm{s})$; and (4) observed debris flow depths that ranged from approximately $1.0 \mathrm{~m}$ uphill the present deposition basin to $0.3-0.5 \mathrm{~m}$ at the debris front.

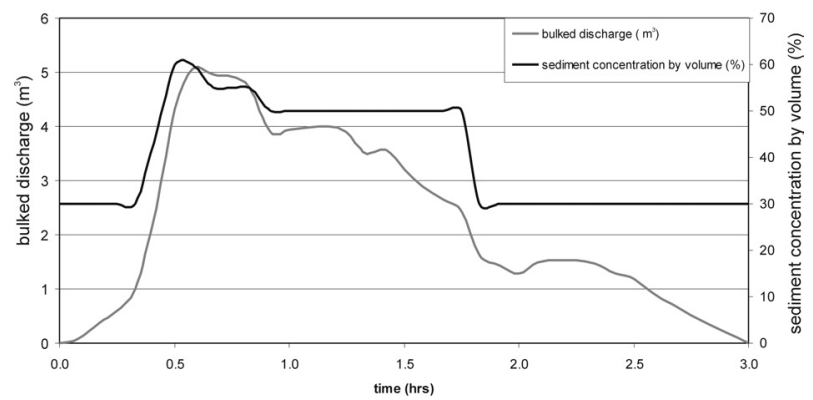

Figure 2: $\quad$ September 5, 1997 hydrograph.

As rheological analyses of the material were not available, several simulations were carried out to back calculate the optimal parameters combinations of $\eta$ and $\tau_{\mathrm{y}}$. To compute viscous and yield stresses appropriate values for $\alpha_{\mathrm{i}}$ and $\beta_{\mathrm{i}}$ were selected from O'Brien [13].

The model results were evaluated through a comparison with field data and the verification of volume conservation. The best agreement between observations and calculations were obtained by the $\alpha_{\mathrm{i}}$ and $\beta_{\mathrm{i}}$ values listed in Table 3, calculated for a sediment concentration by volume of $50 \%$.

Table 2: $\quad$ Empirical coefficients, calculated yield stress and viscosity used for the simulations.

\begin{tabular}{cccccc}
\hline$\alpha_{1}$ (poises) & $\beta_{1}$ & viscosity $\eta(\mathrm{Pa} \mathrm{s})$ & $\alpha_{2}\left(\mathrm{dyn} / \mathrm{cm}^{2}\right)$ & $\beta_{2}$ & yield stress $(\mathrm{Pa})$ \\
\hline 0.0075 & 14.39 & 1.0 & 0.152 & 18.7 & 175 \\
\hline
\end{tabular}

\subsubsection{Simulations of the design debris flow}

The simulation of the design debris flow associated to an extreme meteorological event, is crucial to evaluate the hazard of an area and to plan and predict the efficiency of mitigation measures.

In order to delineate the debris flow hazard, the potential sediment yield in the upstream watershed was investigated. The possible sources of sediment include an area of loose coarse debris between the elevations of $2178-1820 \mathrm{~m}$ a.s.1., channel bank failures and channel bed scour. A precise estimation of the design debris flow has been obtained from seismic refraction investigations in the possible sources of sediment. From the analysis of the ten refraction tomographies, performed in the initiation area, in the upper and middle slope, between the elevations 1832-1624 m a.s.l., the thickness and state of compaction 
of sediment have been determined. The potential sediment volume that can be mobilized results approximately $30000 \mathrm{~m}^{3}$. The in situ void ratio, measured in the initiation area ranges from $0.33-0.36$, so the potential volume of solids is about $20000 \mathrm{~m}^{3}$. Assuming a mean sediment concentration of $50 \%$ by volume, the designed bulked hydrograph results of a total volume of $40000 \mathrm{~m}^{3}$.

Five debris flow routing scenarios have been analysed: (1) the debris flow does not have constraints over the slope, and routes the flow paths determined by the topography from the triggering zone; (2) the debris flow runs only along the main channel (c), simulating the obstruction of channels (a) and (b); (3) the debris flow propagates through the channels (a) and (b), simulating the obstruction of the main channel (c); (4) the debris flow propagates in all the three channels, simulating the worst scenario in terms of extent of the flooded area; (5) this scenario considers the presence and evaluate the efficiency of a protection dike in the previous simulation.

\subsubsection{Simulation hydrograph}

The hydrologic model CLEM (Cazorzi [28]) has been used to predict the design storm rainfall-runoff hydrograph, assuming the same flow velocities previously used. The maximum annual rainfall series from 1984 to 2004 of the Faloria (BL) station have been analysed; the design hydrograph has been obtained, considering the upper confidence limits of depth-duration-frequency curve for a return period of 200 years. The hydrograph has then be bulked with sediment for flood routing over the slope adding sediment as a concentration by volume following the same criteria as in the simulation of the September 5, 1997 event (fig.3).

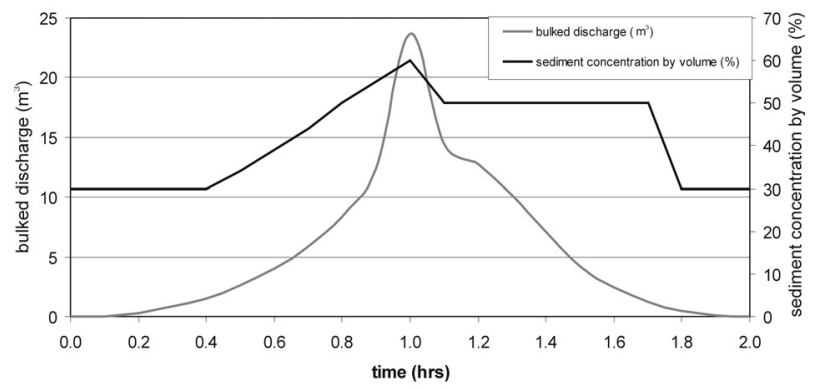

Figure 3: Design hydrograph.

\subsubsection{Results}

It was noted that in all the simulations, volume conservation was observed on the order of $10 \mathrm{~m}^{3}$ or less.

Figure 4 shows the results of the simulation of the September 5, 1997 event that correctly reproduced extent and depth of the debris flow.

The maximum velocities in the axial flow path computed in the model were $1.2 \mathrm{~m} / \mathrm{s}-1.8 \mathrm{~m} / \mathrm{s}$ below $1480 \mathrm{~m}$ a.s. $1 .$, and $3.6 \mathrm{~m} / \mathrm{s}-4.2 \mathrm{~m} / \mathrm{s}$ in the channel, with peaks of $4.8 \mathrm{~m} / \mathrm{s}-5.5 \mathrm{~m} / \mathrm{s}$. These velocities are lower than those estimated by 
measuring superelevations of flow in bends. Recent studies, however, have shown that these values are usually overestimated (Jakob et al. [17]). The calculated runout distance matches with the observed one. The estimated thickness of the deposits is consistent with the field observations: in fact the thickness on the slope below $1480 \mathrm{~m}$ a.s. 1 . is on the order of $0.6 \mathrm{~m}-0.8 \mathrm{~m}$, with peaks of $1.1 \mathrm{~m}-1.3 \mathrm{~m}$ in the axial path of the flow (Table 3 ).

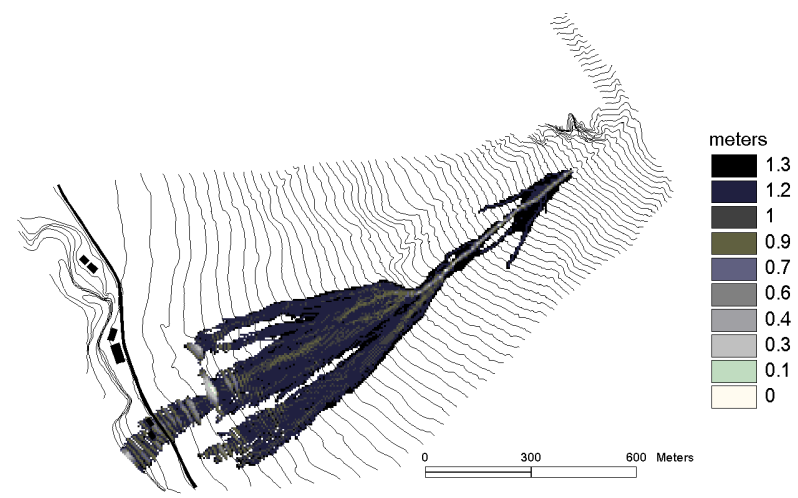

Figure 4: $\quad$ FLO-2D maximum depth inundation map of September 5, 1997.

Table 3: $\quad$ Comparison between computed results and field data.

\begin{tabular}{cccccc}
\hline & $\begin{array}{c}\text { runout } \\
(\mathrm{m})\end{array}$ & $\begin{array}{c}\text { flooded } \\
\text { area }\left(\mathrm{m}^{2}\right)\end{array}$ & $\begin{array}{c}\text { channel max } \\
\text { velocity }(\mathrm{m} / \mathrm{s})\end{array}$ & $\begin{array}{c}\text { dep.area } \max \\
\text { velocity }(\mathrm{m} / \mathrm{s})\end{array}$ & $\begin{array}{c}\text { max flow } \\
\text { depth }(\mathrm{m})\end{array}$ \\
\hline computed & 1500 & 247000 & $2.2-4.0$ & $1.2-1.8$ & $1.1-1.3$ \\
observed & 1500 & 240000 & & $2.9-4.0$ & $0.8-1.1$ \\
\hline
\end{tabular}

Figure 4 highlights that the retention basin built after the event of September 1997 is not sufficient to contain a debris flow of $25000 \mathrm{~m}^{3}$. The basin in fact was designed considering only the volume deposited upstream the main road, not taking into account that about the $48 \%$ of the total volume flowed further downstream and deposited in the Boite River talweg.

When routing the design debris flow, in the scenario (1), the maximum flow depths along the axial direction of the flow, range from $0.8 \mathrm{~m}$ to $1.7 \mathrm{~m}$ on the natural deposition area, below $1480 \mathrm{~m}$ a.s.1., and from 0.4 to $0.8 \mathrm{~m}$ on the adjacent flooded area, with maximum velocities ranging from $3 \mathrm{~m} / \mathrm{s}$ to $5.5 \mathrm{~m} / \mathrm{s}$ in the channel and $1.2 \mathrm{~m} / \mathrm{s}-1.8 \mathrm{~m} / \mathrm{s}$ in the deposition area. The total flooded area is $247000 \mathrm{~m}^{2}$. The depths of the channel are not enough deep to avoid avulsion along the flow path.

The depth and velocity data obtained in the scenario (2) are very close to the ones of the scenario (1); only the extent of the inundated area is smaller (232 000 $\mathrm{m}^{2}$ ). Where the channel branches off at an elevation of $1480 \mathrm{~m}$ a.s.l. the debris deposits (flow depths of $0.9-1.3 \mathrm{~m}$ ) reducing the channel storing capacity, and sediment spread on the slope. 
If the main channel (c) is clogged (scenario (3)) the flow propagates into channels (a) and (b); the estimated thickness ranges from $0.7-2.2 \mathrm{~m}$ in the existing retention basin and $0.5-0.7 \mathrm{~m}$ in the adjacent flooded area, whose extent is $246000 \mathrm{~m}^{2}$. The flow reaches also in this case the Boite River. Maximum velocities are $1.7 \mathrm{~m} / \mathrm{s}$ to $3.3 \mathrm{~m} / \mathrm{s}$ at the retention basin and $1.7 \mathrm{~m} / \mathrm{s}$ to $3.7 \mathrm{~m} / \mathrm{s}$ in the channel.

The scenario (4) depicts the worst situation in terms of extent of inundated area, that is estimated $291000 \mathrm{~m}^{2}$ (fig. 5); a certain amount flowed again to the Boite River. The maximum flow depth range from $0.6 \mathrm{~m}$ to $1.9 \mathrm{~m}$ in the existing retention basin with maximum velocities ranging from $1.3 \mathrm{~m} / \mathrm{s}$ to $2.5 \mathrm{~m} / \mathrm{s}$. In the adjacent flooded area, sediment thickness is on the order of $0.2-0.4 \mathrm{~cm}$; maximum velocities in the channel range from 1.3 to $2.9 \mathrm{~m} / \mathrm{s}$. It is evident that the efficiency of the retention basin is partial, as it intercepts only a part of the whole flowing mass.

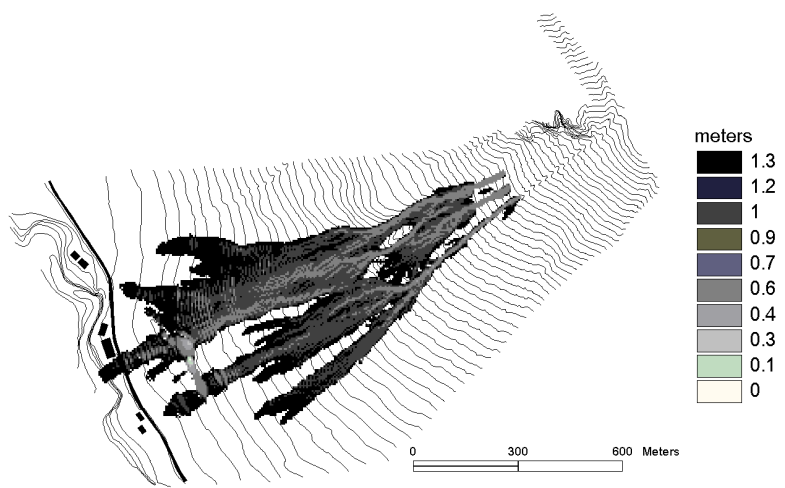

Figure 5: $\quad$ FLO-2D maximum depth inundation map of scenario (4).

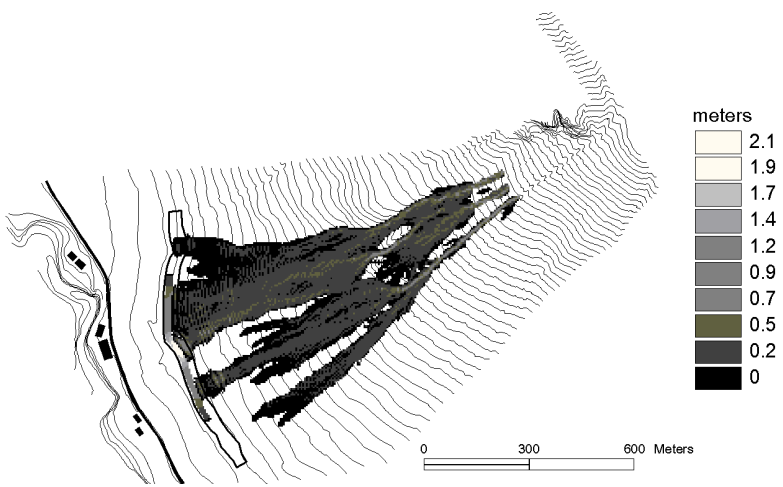

Figure 6: FLO-2D maximum depth inundation map of scenario (5). 
The simulation of scenario (5) is run hypothesizing the presence of a dike $775 \mathrm{~m}$ long, $4 \mathrm{~m}$ high and $20 \mathrm{~m}$ wide, developing along the elevation $1314 \mathrm{~m}$ a.s.1.. The length of the dike results from a series of simulations, starting from the size of the existing retention basin to the reaching of its complete efficiency.

Figure 6 shows that the debris halts in the retention basin, with maximum flow depths ranging from $0.9 \mathrm{~m}$ to $2.1 \mathrm{~m}$ and velocities from $1.0 \mathrm{~m} / \mathrm{s}$ to $3.0 \mathrm{~m} / \mathrm{s}$. Maximum flow depths and velocities in the adjacent inundated area $\left(265000 \mathrm{~m}^{2}\right)$ are $0.5 \mathrm{~m}$ to $0.9 \mathrm{~m}$ and $0.7 \mathrm{~m} / \mathrm{s}$ to $1.0 \mathrm{~m} / \mathrm{s}$ respectively; velocities in the channels range between $2 \mathrm{~m} / \mathrm{s}$ to $3 \mathrm{~m} / \mathrm{s}$.

\section{Conclusions}

The application of FLO-2D can improve the capability to predict debris flow behaviour and estimated depths and velocities, identify areas of inundation delineating hazard maps and implementing zoning restrictions, and design measures for hazard mitigation. Calibration of the model on a well-documented debris flow is a crucial aspect for the accuracy of the simulations aimed to prediction of design event, for choosing the most reliable rheological parameters to be used in the simulations of design events. The simulation of the September 5, 1997 shows that the general flow behaviour is well replicated in terms of extent of the flooded area, runout distance, estimated thickness and velocity using a viscosity of $1.0 \mathrm{~Pa} \mathrm{~s}$ and a yield stress of $175 \mathrm{~Pa}$, calculated from the back analysis of the event. These parameters have been used to predict debris flow behaviour in different scenarios to evaluate the efficiency of the existing mitigating measures and to design the most suitable countermeasures.

\section{References}

[1] Suwa H., Field observation of debris flow. Proc. Japan-China Joint Seminar on Natural Hazard Mitigation, Kyoto, Japan, pp. 343-352, 1989.

[2] Zhang S., A comprehensive approach to the observation and prevention of debris flows in China. Natural Hazards, 7, pp. 1-23, 1993.

[3] Tecca P.R., Galgaro A., Genevois R. \& Deganutti A., Development of a remotely controlled debris flow monitoring system in the Dolomites (Acquabona, Italy). Hydrological Processes, 17, pp. 1771-1784, 2003.

[4] Arattano M. \& Marchi L., Video-derived velocity distribution along a debris flow surge. Physics and Chemistry of the Earth, 25(9), pp. 781-784, 2000 .

[5] De Leon A. \& Jeppson R.W., Hydraulic and numerical solutions of steady-state but spatially varied debris flow. Hydraulics and hydrology series, UWRL/H-82/03, Utah State Univ.: Logan, Utah, 1982.

[6] Schamber D.R. \& MacArthur R.C., One-dimensional model for mudflows. Proc. ASCE Spec. Conf.. Vol. 2, ASCE, pp. 1334-1339, 1985.

[7] MacArthur R.C. \& Schamber D.R., Numerical methods for simulating mudflows. Proc. Third International Symp. On River Sedimentation, Univ. of Mississippi, at Logan, Oxford, pp. 1615-1623, 1986. 
[8] Takahashi T. \& Tsujimoto H., Delineation of the debris flow hazardous zone by a numerical simulation method. Proc. International Symp. On Erosion, debris Flow and Disaster Prevention, Tsukuba, Japan, pp. 457462, 1985.

[9] Takahashi T. \& Nakagawa H., Debris flow hazard zone mapping. Proc. Japan-China (Taipei) Joint seminar on Natural Hazard Mitigation, Kyoto, Japan, pp. 363-372, 1989.

[10] O'Brien J.S. and Julien P.Y., Physical properties and mechanics of hyperconcentrated sediment flows. Proc. ASCE Spec.Conf. on Delineation of Landslides, Flash Floods and Debris Flow Hazards in Utah, University of Utah at Logan, Utah, pp. 260-279, 1985.

[11] O’Brien J.S., Julien P.Y., Fullerton W.T., Two-dimensional water flood and mudflow simulation. Journal of Hydraulic Engineering, 119(2), pp. 244-259, 1993.

[12] FLO-2D, 2-Dimensional Flood Routine Model Manual. Version 2004.10. FLO-2D Software Inc., Nutrioso, AZ 85932, 2004.

[13] O'Brien J.S. and Julien P.Y., Laboratory analysis of mudflows properties. Journal of Hydraulic Engineering, 114(8), pp. 877-887, 1988.

[14] O'Brien J.S., Reasonable assumptions in routing a dam break mudflow. Third International Conference on Debris-flow Hazards Mitigation: Mechanics, Prediction and Assessment, Davos, Switzerland, eds. D. Rickenmann \& C. Chen, Millpress: Rotterdam, pp. 683-693, 2003.

[15] Cazorzi F., HyGrid2k2, Guida di riferimento. Università degli Studi di Udine, 2002.

[16] Johnson A.M. \& Rodine J.R., Debris flow (Chapter 8). Slope Instability, eds. D. Brunsden \& D.B. Prior, Wiley: Chichester, pp. 257,361, 1984.

[17] Jakob M., Hungr O. \& Thomson B., Two debris flows with anomalously high magnitude, First International Conference on Debris-flow Hazards Mitigation: Mechanics, Prediction and Assessment, S. Francisco, California, ed. C. Chen, ASCE: New York, 817, pp. 382-394, 1997. 